\title{
PROSPEKTIF LEMPUNG ALAM CENGAR SEBAGAI ADSORBEN POLUTAN ANORGANIK DI DALAM AIR: KAJIAN KINETIKA ADSORPSI KATION Co(II)
}

\author{
Muhdarina $^{1^{*} \text {, }}$ Abdul Wahab Mohammad ${ }^{2)}$ dan Andanastuti Muchtar ${ }^{3)}$ \\ 1) Jurusan Kimia, Fakultas Matematika dan Ilmu Pengetahuan Alam, Universitas Riau, \\ Kampus Bina Widya, Simpang Baru, Tampan Pekanbaru 28293, telp, +6276163273 \\ ${ }^{2)}$ Jabatan Kejuruteraan Kimia \& Proses, Fakulti Kejuruteraan \& Alam Bina, \\ Universiti Kebangsaan Malaysia, 43600 UKM Bangi \\ Selangor Darul Ehsan, Malaysia \\ ${ }^{3)}$ Jabatan Kejuruteraan Mekanik \& Bahan, Fakulti Kejuruteraan \& Alam Bina, \\ Universiti Kebangsaan Malaysia, 43600 UKM Bangi \\ Selangor Darul Ehsan, Malaysia \\ *Penulis korespondensi: muhdarina@yahoo.com
}

\begin{abstract}
Abstrak
Kemampuan lempung alam Cengar untuk melepaskan kation Co(II) dari air limbah model telah diuji dengan proses adsorpsi. Lempung alam Cengar diimpregnasi dengan larutan garam ammonium 1 molar untuk meningkatkan kemampuan adsorpsinya. Kapasitas adsorpsi kation Co(II) oleh lempung Cengar yang diimpregnasi meningkat di bawah pengaruh waktu kontak dan menurun dengan temperatur. Beberapa model kinetika yaitu order-pertama pseudo, order-kedua pseudo, model Elovich dan difusi intra-partikel telah digunakan untuk mengevaluasi kinetika dan mekanisme interaksi Co(II) pada lempung Cengar. Mekanisme adsorpsi Co(II)-lempung Cengar mengikuti kinetika order-kedua pseudo pada waktu perolehan adsorbat maksimum 120 menit. Dengan model Elovich didapatkan adsorben lempung Cengar memiliki permukaan yang heterogen. Energi aktivasi proses adsorpsi juga dievaluasi di bawah pengaruh temperatur dan didapatkan energi aktivasi yang negatif.
\end{abstract}

Kata kunci: energi aktivasi negatif, kinetika, larutan garam ammonium, lempung alam Cengar

\begin{abstract}
Cengar natural clay was investigated its ability to remove Co(II) cations from wastewater model through the adsorption process. The Cengar natural clay was impregnated by 1 molar of ammonium salts solution to increase its uptake ability. The adsorption capacity of Co(II) cation on Cengar impregnated clay increased under the contact time effect and decreased by temperature effect. A number of available models like: pseudo first-order, pseudo second-order, Elovich model and intraparticle diffusion, respectively, were utilized to evaluate the kinetics and mechanism of the interaction of Co(II) cations on Cengar clay. The adsorption mechanism of Co(II) cation-Cengar clay interaction followed the pseudo second-order kinetic with the maximum uptake time observed within 120 minutes. By Elovich model showed that the adsorbent of Cengar clay has heterogeneous surface. Its activation energy of adsorption was also evaluated under the variable of temperature and gave the negative activation energy.
\end{abstract}

Keywords: negative activation energy, kinetic, ammonium salt solution, Cengar natural clay

\section{PENDAHULUAN}

Keberadaan polutan logam berat di dalam badan air merupakan masalah lingkungan saat ini yang secara signifikan memberi dampak negatif terhadap kualitas sumber air karena material ini bersifat toksik dan tidak terbiodegradasi. Peningkatan konsentrasi logam berat di lingkungan menyebabkan logam-logam tersebut terkumpul di dalam rantai kehidupan air tumbuhan - hewan - manusia sehingga menjadi ancaman yang luar biasa bagi metabolisme kehidupan. Karena itu, adanya logam berat di dalam air akan membahayakan kesehatan karena daya racunnya yang tinggi (Naiya et al., 2009). Prayitno (2008) merekomendasikan setidaknya ada dua tindakan yang 
harus ditaati untuk mengatasi pencemaran lingkungan air. Pertama berupa tindakan pencegahan, industri diwajibkan mengolah limbah terlebih dahulu sampai tingkat aman tertentu sebelum dibuang ke perairan dan kedua menyingkirkan polutan yang terlanjur terdedah ke badan perairan untuk menurunkan kadar polutan sehingga air tersebut layak digunakan untuk berbagai keperluan sehari-hari.

Adsorpsi telah terbukti sebagai suatu metoda yang lebih efektif untuk melepaskan polutan logam berat dari air limbah jika dibandingkan dengan proses lain seperti pengendapan kimia, pertukaran ion, osmosis terbalik, dan elektrolisis (Eren and Afsin, 2008). Menurut Manohar et al. (2006), metoda adsorpsi sangat efektif untuk limbah dengan konsentrasi polutan yang rendah sampai sedang. Adsorpsi adalah proses pemusatan molekul atau ion adsorbat pada lapisan permukaan adsorben, baik secara fisika atau kimia. Dengan demikian adsorben harus mempunyai sifat-sifat permukaan yang khas sesuai dengan jenis adsorbat yang teradsorpsi. Proses adsorpsi pada karbon aktif atau resin organik dan inorganik merupakan teknik yang cukup efektif, namun terkendala oleh biaya operasional yang tinggi sehingga perlu dicari adsorben alternatif dengan biaya yang relatif murah.

Mineral lempung yang merupakan konstituen penting di dalam tanah berperan sebagai perangkap alami polutan-polutan yang mengalir bersama air di permukaan atau di dalam tanah melalui peristiwa adsorpsi atau pertukaran ion. Berdasarkan peran tersebut serta ditambah dengan kelimpahannya di alam, maka cukup beralasan menganggap lempung alam sebagai adsorben yang murah (Bhattacharyya and Gupta, 2008b; Eren and Afsin, 2008). Keunggulan lempung sebagai adsorben ditunjang pula oleh sifatsifat yang dimilikinya antara lain luas permukaan spesifik yang tinggi, stabil secara kimia dan mekanik, struktur permukaan yang bervariasi, kapasitas pertukaran ion yang tinggi serta adanya asam-asam Bronsted dan Lewis (Bhattacharyya and Gupta, 2006). Beberapa laporan tentang kemampuan adsorpsi logam berat oleh lempung telah ditunjukkan, seperti bentonit efektif untuk melepaskan $\mathrm{Pb}(\mathrm{II}), \mathrm{Cd}(\mathrm{II}), \mathrm{Cu}(\mathrm{II})$, dan $\mathrm{Zn}$ (II) dari air (Gozen et al., 1998), juga menjerap $\mathrm{Co}$ (II) menurut kinetika resapan eksternal (Shahwan et al., 2006), kation $\mathrm{Cd}^{2+}$ dapat diadsorpsi oleh mineral illit (Echeverria et al., 2002), kaolinit menjerap kationkation $\mathrm{Pb}^{2+}, \mathrm{Zn}^{2+}$ dan $\mathrm{Cd}^{2+}$ (Miranda-Trevino et al., 2003) serta kation $\mathrm{Co}^{2+}$ sesuai dengan kinetika orderpertama pseudo (Yavuz et al., 2003), lempung yang terdiri atas mineral kaolin dan illit mempunyai kapasitas retensi yang tinggi terhadap logam $\mathrm{Cu}$ (Bellir et al., 2005), lempung Sarooj, Oman, dapat menghilangkan logam $\mathrm{Zn}, \mathrm{Cd}$ dan $\mathrm{Pb}$ dari dalam air (Abu-Eishah, 2008).

Lempung merupakan polimer anorganik alam berupa hidrat aluminosilikat. Secara luas lempung telah dikenal sebagai fraksi-fraksi halus koloid $( \pm 2$ $\mu \mathrm{m})$ dari tanah, sedimen atau batu-batuan. Apabila lempung menyerap air, ia bersifat seperti plastik dan sebaliknya akan mengeras jika terdehidrasi. Lempung disusun secara berlapis-lapis dengan ruangan antar lapis dan setiap lapisan dapat bersifat netral atau bermuatan listrik. Lempung alam Cengar yang menjadi objek kajian ini tergabung di dalam batubatuan berwarna kuning kecoklatan yang terdapat di pinggiran anak sungai Kuantan di Desa Cengar, Kuantan Singingi (Kuansing), Provinsi Riau. Kenyataan yang nampak di sungai ini, air yang mengalir melewati lempung Cengar tidak bewarna atau jernih. Penelitian ini bertujuan untuk menjajaki prospektif penggunaan lempung Cengar sebagai adsorben untuk melepaskan logam berat Co dari dalam air dengan memfokuskan kajian pada aspek kinetika adsorpsi. Pengetahuan model kinetik suatu sistem adsorpsi diperlukan untuk merancang suatu proses adsorpsi yang lebih ekonomis, sesuai dengan masa tinggal reaktan dan dimensi reaktor (Ho, 2006; Gupta and Babu, 2009). Diantara model kinetik yang dipilih untuk melacak sistem adsorpsi logam Co oleh lempung Cengar adalah order-pertama pseudo, orderkedua pseudo, model Elovich, dan difusi intrapartikel.

\section{METODE PENELITIAN \\ Penyiapan Adsorben dan Adsorbat}

Batuan lempung alam Cengar diambil secara acak di lokasi, dicuci, dan dikering-anginkan selama beberapa hari. Batuan ini dihaluskan dengan grinder dan diayak dengan ukuran partikel 300-500 $\mu \mathrm{m}$. Serbuk lempung direndam di dalam air suling selama 5 jam sambil sesekali diaduk dan didiamkan satu malam. Cairan bagian atasnya dipisahkan dan suspensi bagian bawah disaring dan dikeringkan pada suhu kamar selama beberapa hari. Analisis komposisi dengan XRD menunjukkan bahwa lempung alam Cengar mengandung mineral kaolinit, muskovit, dan kuarsa.

Semua bahan kimia yang digunakan berkualitas analitik dan disiapkan dalam keadaan segar. $\mathrm{CH}_{3} \mathrm{COONH}_{4}$ dan $\mathrm{NH}_{4} \mathrm{Cl}$ (Fisher Scientific) masingmasing disiapkan sebanyak $500 \mathrm{ml} 1 \mathrm{M}$ dengan air destilasi. Adsorbat limbah $\mathrm{Co}(\mathrm{II})$ dibuat dengan menyediakan larutan stock $100 \mathrm{mgl}^{-1} \mathrm{Co}(\mathrm{II})$ dari garam $\mathrm{Co}\left(\mathrm{NO}_{3}\right)_{2} \cdot 6 \mathrm{H}_{2} \mathrm{O}$ (Merck) dalam air destilasi dan diencerkan sesuai konsentrasi yang diinginkan.

Sampel adsorben disiapkan dengan merendam 10 gram serbuk lempung ke dalam $500 \mathrm{ml} 1 \mathrm{M}$ $\mathrm{CH}_{3} \mathrm{COONH}_{4}$ atau $\mathrm{NH}_{4} \mathrm{Cl}$ selama 5 jam sambil diaduk konstan dan didiamkan satu malam. Suspensi disaring menggunakan pompa vakum, pastinya dicuci dengan $50 \mathrm{ml}$ air suling secara lambat sambil disaring sehingga bebas ion klorida (untuk $\mathrm{NH}_{4} \mathrm{Cl}$ ) dan dikeringkan pada suhu kamar selama 2 hari. Sampel diberi kode dengan INC-AA $\left(\mathrm{CH}_{3} \mathrm{COONH}_{4}\right)$, INC-AC $\left(\mathrm{NH}_{4} \mathrm{Cl}\right)$ dan INC-O (blanko). 


\section{Eksperimen Adsorpsi}

Eksperimen adsorpsi dibuat secara tumpak di dalam sebuah water bath shaker dengan suhu, waktu, dan pengadukan yang terkontrol. Sebanyak $10 \mathrm{ml}$ larutan adsorbat dan 0,1 gram adsorben dimasukkan ke dalam sebuah labu erlenmeyer $50 \mathrm{ml}$ dan ditempatkan ke dalam water bath shaker. Setelah waktu dan temperatur yang ditentukan fasa padat adsorben dipisahkan dari larutan dengan cara sentrifugasi. Variabel yang diamati: waktu kontak adsorben-adsorbat $\left(\mathrm{t}=0-3 \mathrm{jam}\right.$ pada $\mathrm{C}_{0} 3 \mathrm{mgl}^{-1}, \mathrm{~T}=$ $\left.30 \pm 1^{\circ} \mathrm{C}, \mathrm{r}=20 \mathrm{rpm}, \mathrm{pH}=3,8\right)$, dan temperatur adsorpsi $\left(\mathrm{T}=30-60^{\circ} \mathrm{C}\right.$ pada $\mathrm{C}_{0} 3 \mathrm{mgl}^{-1}, \mathrm{t}=2 \mathrm{jam}, \mathrm{r}=120 \mathrm{rpm}, \mathrm{pH}=$ $3,8)$.

\section{Analisis dan Evaluasi Data}

Konsentrasi adsorbat dalam filtrat diukur secara spektroskopi serapan atom (SOLAAR32 AA Spectrometer) pada $\lambda=240,7 \quad \mathrm{~nm}$. Sebelum pengukuran, filtrat adsorbat diencerkan dari $1 \mathrm{ml}$ menjadi $10 \mathrm{ml}$ dengan air destilasi dan dibuat 3 replikat. Jumlah adsorbat pada kesetimbangan, $\mathrm{q}_{\mathrm{e}}$, dihitung menurut:

$$
\mathrm{q}_{\mathrm{e}}=\frac{\mathrm{V}\left(\mathrm{C}_{0}-\mathrm{C}_{\mathrm{e}}\right)}{\mathrm{m}}
$$

Dengan $\mathrm{C}_{0}$ dan $\mathrm{C}_{\mathrm{e}}$ masing-masing konsentrasi awal dan konsentrasi pada kesetimbangan $(\mathrm{mg} / \mathrm{l})$ adsorbat dalam fasa cair, V, volume larutan adsorbat (1), dan m, masa adsorben (g). Data yang diperoleh selanjutnya dievaluasi sesuai dengan model kinetik yang dipilih, persamaan (4), (6), (8) dan (9).

\section{Teori Kinetika}

Umumnya mekanisme adsorpsi larutan adsorbat pada material adsorben mengikuti 4 tahap berikut (Argun et al., 2007; Crini et al., 2 007; Gupta and Bhattacharyya, 2008; Naiya et al., 2009) yaitu: (i) perpindahan larutan adsorbat menuju permukaan adsorben (difusi pukal); (ii) difusi adsorbat melalui bidang batas permukaan adsorben (difusi filem); (iii) pemindahan adsorbat dari permukaan ke pori interior partikel adsorben (difusi intra-partikel atau difusi pori); (iv) adsorpsi partikel adsorbat pada situs aktif permukaan adsorben (reaksi kimia via pertukaran ion, kompleksasi dan/atau khelat).

Model-model kinetika yang dipilih untuk kajian sistem adsorpsi kation Co(II) pada lempung Cengar ini diantaranya order-pertama pseudo, order-kedua pseudo, dan model Elovich yang didasarkan kepada kapasitas adsorpsi dengan laju penjerapan yang dikawal oleh kemisorpsi (Crini et al., 2007; Gupta and Babu, 2009), difusi intra-partikel dan difusi film untuk sistem adsorpsi yang dikontrol oleh difusi (Al-Degs et al., 2006, Crini et al., 2007; Naiya et al., 2009).

\section{Model kinetika order-pertama pseudo}

Persamaan kinetik order-pertama pseudo oleh Lagergren dinyatakan sebagai berikut:

$$
\frac{\mathrm{dq}_{\mathrm{t}}}{\mathrm{dt}}=\mathrm{k}_{1}\left(\mathrm{q}_{\mathrm{e}}-\mathrm{q}_{\mathrm{t}}\right)
$$

Pengintegrasian pada kondisi $t=0-t$ dan $q_{t}=0-q_{t}$ maka persamaan menjadi:

$$
\ln \left(\frac{\mathrm{q}_{\mathrm{e}}}{\mathrm{q}_{\mathrm{e}}-\mathrm{q}_{\mathrm{t}}}\right)=\mathrm{k}_{1} \mathrm{t}
$$

Dan bentuk linearnya adalah:

$$
\ln \left(\mathrm{q}_{\mathrm{e}}-\mathrm{q}_{\mathrm{t}}\right)=\ln \mathrm{q}_{\mathrm{e}}-\mathrm{k}_{1} \mathrm{t}
$$

dengan $\mathrm{q}_{\mathrm{e}}$ dan $\mathrm{q}_{\mathrm{t}}$ adalah jumlah adsorbat yang terjerap pada waktu kesetimbangan dan waktu $\mathrm{t}\left(\mathrm{mg} \mathrm{g}^{-1}\right)$, $\mathrm{k}_{1}$ tetapan laju order-pertama pseudo $\left(\mathrm{min}^{-1}\right)$ proses adsorpsi. Nilai $\mathrm{q}_{\mathrm{e}}$ dan $\mathrm{k}_{1}$ didapat dari plot $\ln \left(\mathrm{q}_{\mathrm{e}}-\mathrm{q}_{\mathrm{t}}\right)$ versus $t$, dengan $k_{1}$ slope dan $q_{e}$ intercept (Gupta and Bhattacharyya, 2005; Al-Degs et al., 2006; Crini et al., 2007; Gupta and Bhattacharyya, 2008; Gupta and Babu, 2009; Naiya et al., 2009).

\section{Model kinetika order-kedua pseudo}

Beberapa kasus adsorpsi adakalanya mengikuti kinetika order-kedua pseudo sesuai persamaan:

$$
\frac{\mathrm{dq}_{\mathrm{t}}}{\mathrm{dt}}=\mathrm{k}_{2}\left(\mathrm{q}_{\mathrm{e}}-\mathrm{q}_{\mathrm{t}}\right)^{2}
$$

Pada batas $\mathrm{t}=0-\mathrm{t}$ dan $\mathrm{q}_{\mathrm{t}}=0-\mathrm{q}_{\mathrm{t}}$, maka bentuk linear dari integrasinya ditulis sebagai:

$$
\frac{\mathrm{t}}{\mathrm{q}_{\mathrm{t}}}=\frac{1}{\mathrm{k}_{2} \mathrm{q}_{\mathrm{e}}^{2}}+\frac{\mathrm{t}}{\mathrm{q}_{\mathrm{e}}}
$$

Parameter $\mathrm{q}_{\mathrm{e}}\left(\mathrm{mg} \mathrm{g}^{-1}\right)$ dan $\mathrm{k}_{2}\left(\mathrm{~g} \mathrm{mg}^{-1} \min ^{-1}\right)$ dihitung dari plot $\mathrm{t} / \mathrm{q}_{\mathrm{t}}$ versus $\mathrm{t}$, dengan $\mathrm{h}=\mathrm{k}_{2} \mathrm{q}_{\mathrm{e}}{ }^{2}\left(\mathrm{mg} \mathrm{g}^{-1} \min ^{-1}\right)$ adalah laju serapan awal pada $\mathrm{t} \rightarrow 0$ (Crini et al., 2007; Mane et al., 2007; Anirudhan and Radhakrishnan, 2008; Gupta and Bhattacharyya, 2008; Gupta and Babu, 2009).

\section{Model Elovich}

Model kinetik Elovich dapat mempelajari laju adsorpsi berdasarkan kapasitas jerapan pada permukaan yang heterogen dirumuskan dengan persamaan di bawah ini:

$$
\frac{d q_{t}}{d t}=\alpha \exp \left(-\beta q_{t}\right)
$$

dengan $\alpha$ laju awal adsorpsi $\left(\mathrm{mg} \mathrm{g}^{-1} \min ^{-1}\right)$ dan $\beta$ tetapan desorpsi $\left(\mathrm{g} \mathrm{mg}^{-1}\right)$ yang menyatakan penempatan permukaan oleh adsorbat dan energi aktivasi kemisorpsi (Gupta and Babu, 2009; Nadeem et al., 2009; Noroozifar et al., 2009). Dengan mengambil batas $\mathrm{t}=0-\mathrm{t}, \mathrm{q}_{\mathrm{t}}=0-\mathrm{q}_{\mathrm{t}}$ dan menganggap $(\alpha \beta)>>t$, maka persamaan ini dapat disederhanakan menjadi:

$$
\mathrm{q}_{\mathrm{t}}=\left(\frac{1}{\beta}\right) \ln (\alpha \beta)+\left(\frac{1}{\beta}\right) \ln \mathrm{t}
$$

Slop dan intersep dari plot $\mathrm{q}_{\mathrm{t}}$ versus $\ln \mathrm{t}$ digunakan untuk menghitung nilai $\beta$ dan $\alpha$.

\section{Model difusi intra-partikel}

Weber dan Morris merumuskan model difusi intra-partikel untuk melacak perpindahan adsorbat dari permukaan adsorben ke dalam pori internal akibat pengadukan, sebagai berikut:

$$
\mathrm{q}_{\mathrm{t}}=\mathrm{k}_{\mathrm{i}} \mathrm{t}^{0,5}+\mathrm{C}
$$


dengan $\mathrm{q}_{\mathrm{t}}\left(\mathrm{mg} \mathrm{g}^{-1}\right)$ adalah jumlah adsorbat pada permukaan adsorben, $\mathrm{k}_{\mathrm{i}}\left(\mathrm{mg} \mathrm{g}^{-1} \min { }^{0.5}\right)$ tetapan laju difusi intra-partikel, $\mathrm{t}(\mathrm{min})$ waktu dan $\mathrm{C}\left(\mathrm{mg} \mathrm{g}^{-1}\right)$ adalah intersep. Nilai $\mathrm{k}_{\mathrm{i}}$ diperoleh dengan memplot $\mathrm{q}_{\mathrm{t}}$ versus $\mathrm{t}^{0,5}$. Sistem adsorpsi mengikuti model ini jika garis linear melalui titik nol $(\mathrm{C}=0)$, jika tidak maka laju adsorpsi tidak hanya dikontrol oleh difusi intrapartikel, tetapi ada juga proses yang lain (Al-Degs et al., 2006; Crini et al., 2007; Gupta dan Bhattacharyya, 2008; Naiya et al., 2009). C merupakan ketebalan lapisan batas yang dibentuk oleh proses adsorpsi, semakin besar nilai $\mathrm{C}$ maka semakin besar pula efek lapisan batas ini (Mane et al., 2007).

\section{HASIL DAN PEMBAHASAN Pengaruh Waktu Kontak}

Adsorpsi kation Co(II) oleh lempung Cengar berjalan sangat cepat dalam 60 menit pertama, setelah itu mulai melambat dan mendekati kesetimbangan pada waktu 120 menit, seperti ditunjukkan pada Gambar 1. Sifat adsorben dan adsorbat serta interaksi diantara keduanya merupakan faktor yang mempengaruhi kondisi kesetimbangan. Waktu kesetimbangan yang sama juga dilaporkan oleh Yavuz dkk (2003) untuk sistem adsorpsi Co(II) pada kaolinit. Namun Guerra dan Airoldi (2008) mendapatkan waktu kesetimbangan masing-masing 150 menit dan 100 menit untuk sistem $\mathrm{Co}$ (II)-smectit dan $\mathrm{Co}(\mathrm{II})$ thiol/smectit, Bhattacharyya dan Gupta (2007) memerlukan waktu 4 jam untuk kesetimbangan Co(II)-montmorillonit, sedangkan Fonseca et al. (2005) melaporkan waktu yang lebih lama, 72 jam untuk mencapai kesetimbangan sistem adsorpsi Co(II)-vermiculit.

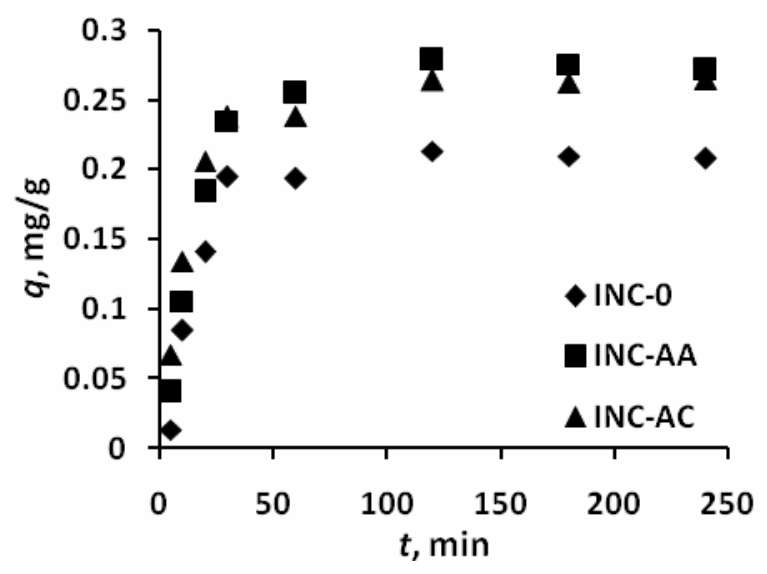

Gambar 1. Pola adsorpsi kation Co(II) oleh lempung Cengar pada berbagai waktu kontak $\left(\mathrm{C}_{0}=3 \mathrm{mgl}^{-1}\right.$, $\left.\mathrm{T}=30 \pm 1^{\circ} \mathrm{C}, \mathrm{r}=120 \mathrm{rpm}, \mathrm{pH}=3,8\right)$

Laju adsorpsi yang tinggi pada awal proses disebabkan karena permukaan lempung masih kosong sehingga kation Co(II) bersaing sesamanya untuk menempati posisi situs aktif lempung. Namun seiring dengan bertambahnya waktu, jumlah situs aktif permukaan semakin berkurang sehingga laju adsorpsi kation Co(II) berkurang pula sampai dicapai kesetimbangan. Laju menuju kesetimbangan ditentukan oleh laju pemindahan ion logam dari fasa cair menuju antar-muka adsorbat-adsorben, Co(II)lempung (Yu et al., 2000; Bhattacharyya and Gupta, 2006; Gupta and Bhattacharyya, 2008). Penyebab lain, dengan bertambahnya waktu maka semakin banyak terbentuk kation terhidrat dengan jari-jari yang lebih besar dari pada jari-jari ion logamnya sehingga menghalangi proses adsorpsi (Erdem et al., 2004; Peric et al., 2004). Adsorpsi kation Co(II) setelah waktu 120 menit ternyata tidak seefisien waktu sebelumnya, sehingga waktu adsorpsi 120 menit dapat dipandang sebagai keadaan mirip-seimbang (quasiequilibrium) dan keadaan tunak (steady state) dicapai (Mane et al., 2006).

\section{Kinetika Adsorpsi \\ Order-pertama pseudo}

Data adsorpsi kation Co(II) oleh lempung Cengar pada berbagai waktu dievaluasi untuk mendapatkan kinetika yang sesuai untuk sistem adsorpsi tersebut. Grafik order-pertama pseudo dari persamaan $4, \ln \left(\mathrm{q}_{\mathrm{e}}-\mathrm{q}_{\mathrm{t}}\right)$ versus $\mathrm{t}$ ditunjukkan pada Gambar 2. Bentuk linear dari grafik ini memberikan tetapan laju $\mathrm{k}_{1}, \mathrm{q}_{\mathrm{e}}$ dan $\mathrm{R}^{2}$ seperti di dalam Tabel 1 . Meskipun nilai koefisien korelasi $\mathrm{R}^{2}=0,91-0,93$ dapat diterima (kecuali INC-O), tetapi nilai $\mathrm{q}_{\mathrm{e}}$ yang diberikan oleh model memiliki deviasi yang lebih tinggi dari $\mathrm{q}_{\mathrm{e}}$ yang diperoleh dari eksperimen (Tabel 2), maka model kinetika order-pertama pseudo tidak terpenuhi untuk sistem adsorpsi kation $\mathrm{Co}(\mathrm{II})$ pada lempung Cengar.

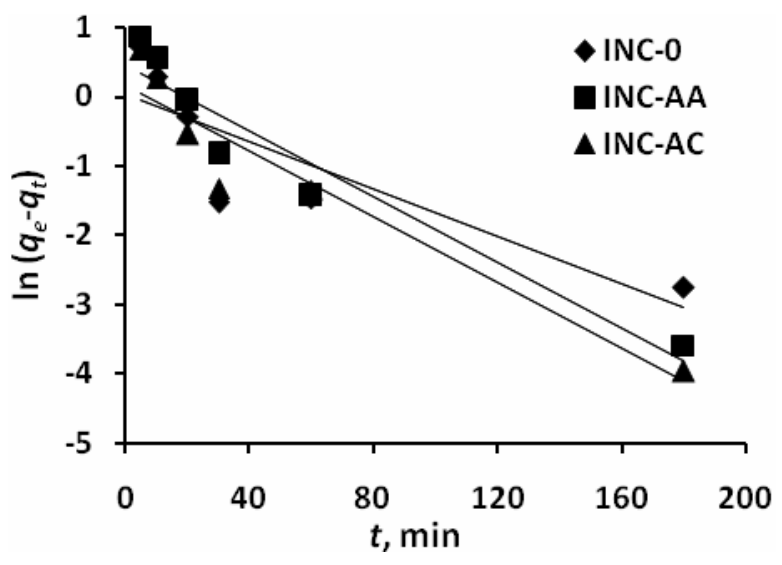

Gambar 2. Grafik model kinetika order-pertama pseudo adsorpsi kation Co(II) pada lempung Cengar

\section{Order-kedua pseudo}

Plot $\mathrm{t} / \mathrm{q}_{\mathrm{t}}$ versus $\mathrm{t}$ dari persamaan (6) yang ditunjukkan pada Gambar 3 adalah linear $\left(\mathrm{R}^{2}=0,93\right.$ $0,99)$ dengan tetapan laju $\mathrm{k}_{2}$ dan $\mathrm{q}_{\mathrm{e}}$ seperti tertera pada Tabel 1. Aplikasi data adsorpsi ke dalam model kinetika order-kedua pseudo memberikan nilai $\mathrm{q}_{\mathrm{e}}$ model dan $\mathrm{q}_{\mathrm{e}}$ eksperimen yang tidak jauh berbeda, dengan deviasi yang cukup kecil (Tabel 2). 
Reaktor, Vol. 13 No. 2, Desember 2010, Hal. 81-88

Tabel 1. Nilai parameter model kinetika adsorpsi kation Co(II) oleh lempung Cengar

\begin{tabular}{lcccc}
\hline Model Kinetika & Parameter & INC-O & INC-AA & INC-AC \\
\hline Order-pertama pseudo & $\mathrm{k}_{1} / \mathrm{l}^{-3} \mathrm{~min}^{-1}$ & 1,7 & 2,4 & 2,4 \\
& $\mathrm{q}_{\mathrm{e}}, \mathrm{mg} \mathrm{g}^{-1}$ & 0,102 & 0,158 & 0,119 \\
& $\mathrm{R}^{2}$ & 0,74 & 0,93 & 0,91 \\
Order-kedua pseudo & $\mathrm{k}_{2} / 10^{-3} \mathrm{~g} \mathrm{mg}^{-1} \mathrm{~min}^{-1}$ & 1,5 & 2,2 & 3,9 \\
& $\mathrm{q}_{\mathrm{e}}, \mathrm{mg} \mathrm{g}^{-1}$ & 0,242 & 0,297 & 0,276 \\
& $\mathrm{~h} / 10^{-2} \mathrm{mg} \mathrm{g}^{-1} \mathrm{~min}^{-1}$ & 0,86 & 1,9 & 3,0 \\
Elovich & $\mathrm{R}^{2}$ & 0,93 & 0,99 & 0,99 \\
& $\alpha / 10^{-2} \mathrm{mg} \mathrm{g}^{-1} \min ^{-1}$ & 3,3 & 4,5 & 9,5 \\
Difusi intra-partikel & $\beta, \mathrm{g} \mathrm{mg}^{-1}$ & 21,143 & 16,835 & 21,186 \\
& $\mathrm{R}^{2}$ & 0,82 & 0,87 & 0,84 \\
& $\mathrm{k}_{\mathrm{i}} / 10^{-2} \mathrm{mg} \mathrm{g}^{-1} \mathrm{~min}^{-0.5}$ & 1,2 & 1,5 & 1,2 \\
\hline
\end{tabular}

Tabel 2. Deviasi nilai $\mathrm{q}_{\mathrm{e}, \exp }$ (eksperimen) dan $\mathrm{q}_{\mathrm{e}, \text { mod }}$ (model) dari dua model kinetika order-pertama pseudo dan order-kedua pseudo sistem adsorpsi kation Co(II) pada lempung Cengar.

\begin{tabular}{lccc}
\hline & $\mathrm{q}_{\mathrm{e}, \text { exp }}, \mathrm{mg} \mathrm{g}^{-1}$ & $\mathrm{q}_{\mathrm{e}, \mathrm{mod}}, \mathrm{mg} \mathrm{g}^{-1}$ & Deviasi, \% \\
\hline Order-pertama pseudo & & & \\
INC-O & 0,216 & 0,102 & $+52,8$ \\
INC-AA & 0,275 & 0,158 & $+42,5$ \\
INC-AC & 0,264 & 0,119 & $+54,9$ \\
Order-kedua pseudo & & & \\
INC-O & 0,216 & 0,242 & $-12,3$ \\
INC-AA & 0,275 & 0,297 & $-8,0$ \\
INC-AC & 0,264 & 0,276 & $-4,5$ \\
\hline
\end{tabular}

Deviasi masih ada, berasal dari ketidaktentuan dalam memperoleh data $\mathrm{q}_{\mathrm{e}}$ eksperimen (Gupta and Bhattacharyya, 2008). Dengan demikian mekanisme adsorpsi lebih dominan mengikuti kinetika orderkedua pseudo, artinya kation Co(II) dan permukaan lempung Cengar kedua-duanya secara efektif terlibat di dalam proses. Dengan pemenuhan model ini berarti adsorpsi kation Co(II) pada lempung Cengar berlangsung secara kemisorpsi.

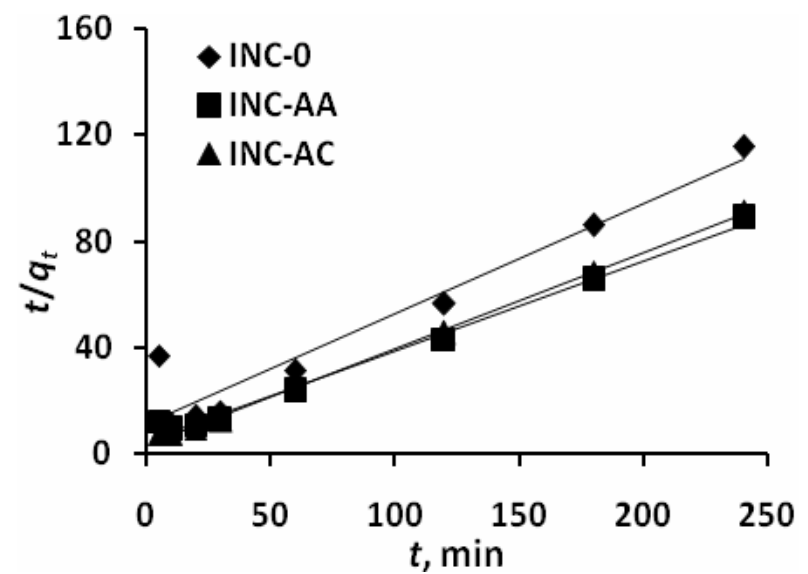

Gambar 3. Grafik model kinetika order pseudo-kedua adsorpsi kation Co(II) pada lempung Cengar.

\section{Model Elovich}

Analisis menggunakan model Elovich ditujukan untuk melacak proses kemisorpsi pada permukaan yang heterogen. Plot $\mathrm{q}_{\mathrm{t}}$ versus $\ln \mathrm{t}$ dari persamaan (8) disajikan sebagai Gambar 4 dengan nilai setiap parameternya tercantum di dalam Tabel 1 . Meskipun nilai $\mathrm{R}^{2}$ kecil $(0,82-0,87)$, namun dengan nilai $\beta$ yang cukup besar dapat menggambarkan bahwa permukaan adsorben lempung Cengar sangat heterogen. Nilai $\beta$ juga untuk menggambarkan kecenderungan energi aktivasi proses adsorpsi kation $\mathrm{Co}(\mathrm{II})$ pada lempung Cengar.

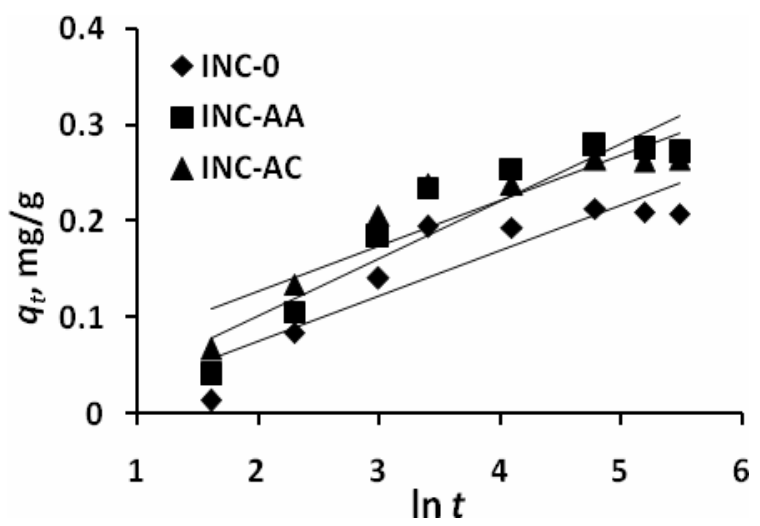

Gambar 4. Grafik model kinetika Elovich adsorpsi kation Co(II) pada lempung Cengar. 


\section{Difusi intra-partikel}

Di dalam sistem tumpak dengan pengadukan cepat, pemindahan adsorbat dari larutan ke pori adsorben mungkin merupakan tahap penentu laju adsorpsi. Kemungkinan itu dapat diuji dengan model yang dirumuskan oleh Weber dan Morris (persamaan 9) dengan membuat plot $q_{t}$ versus $t^{0,5}$ (Gambar 5). Dari grafik tersebut tergambar ada dua fasa yang terjadi selama proses adsorpsi kation Co(II) oleh lempung Cengar, yakni bagian awal plot yang menunjukkan efek lapisan batas (boundary layer) yang berjalan sangat cepat dan bagian kedua berupa difusi ke dalam kerangka polimer lempung atau difusi intra-partikel sebagai pengontrol laju. Grafik multilinear yang sama dilaporkan oleh Crini dkk (2007) untuk sistem adsorpsi zat warna malachite green - cyclodextrin dan brilliant green-abu sekam (Mane et al., 2007).

Nilai setiap parameter dalam persamaan 9 disajikan di dalam Tabel 2. Dari perolehan nilai intersep yang sangat kecil $(C=0,066-0,117)$, maka dapat dikatakan sangat sedikit efek lapisan batas pada sistem adsorpsi kation $\mathrm{Co}(\mathrm{II})$ oleh lempung Cengar. Dengan demikian difusi intra-partikel cukup berperan di dalam proses adsorpsi ini, meskipun nilai koefisien korelasi proses adsorpsi ini kecil $\left(\mathrm{R}^{2}=0,61-0,67\right)$.

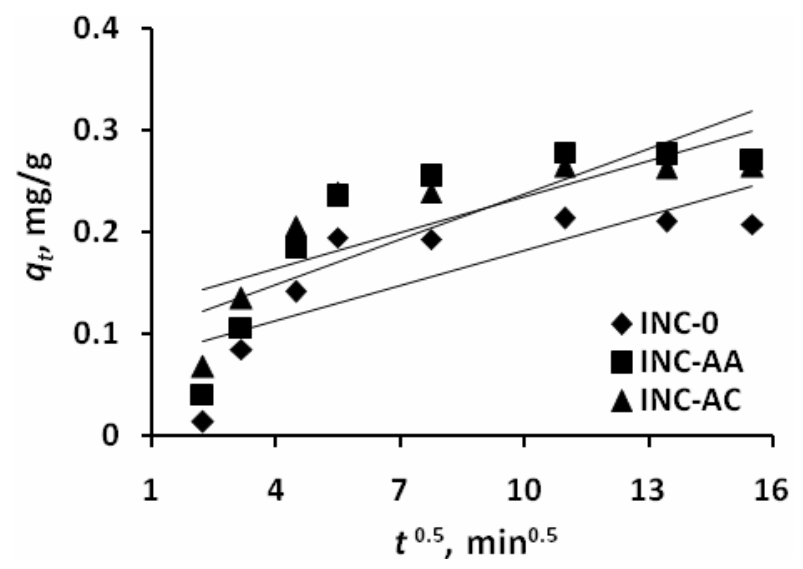

Gambar 5. Grafik model kinetika difusi intra-partikel adsorpsi kation Co(II) pada lempung Cengar.

\section{Efek temperatur dan energi aktivasi adsorpsi}

Jumlah kation Co(II) yang diadsorpsi oleh lempung Cengar tampak berkurang dengan kenaikan temperatur proses (Gambar 6). Secara psikokimia, laju reaksi meningkat dengan kenaikan temperatur, namun keadaan ini umum terjadi pada gas, sedang dalam sistem cair-padat ditentukan oleh faktor-faktor seperti gaya interionik, energi hidrasi, ketersediaan situs aktif permukaan dan stabilitas relatif ion-ion yang teradsorpsi pada situs aktif . Disamping itu reaksi pengikatan logam pada situs adsorpsi permukaan juga membebaskan energi (Shahwan et al., 2006). Interaksi kedua adsorben lempung-adsorbat $\mathrm{Co}(\mathrm{II})$ berjalan secara eksotermis. Pada temperatur tinggi kelarutan ion logam di dalam air meningkat dan pada kondisi yang sama kation logam keluar meninggalkan permukaan fasa padat adsorben. Hal yang sama di dapatkan oleh Gupta dan Bhattacharyya (2008) untuk adsorpsi $\mathrm{Pb}(\mathrm{II})$ dan $\mathrm{Ni}(\mathrm{II})$ pada kaolinit.

Dari keempat model kinetika yang digunakan untuk mengevaluasi adsorpsi $\mathrm{Co}$ (II) pada lempung Cengar ternyata model order-kedua pseudo yang paling memenuhi $\left(\mathrm{R}^{2}=0,93-0,99\right)$. Order yang sama ditemui pula pada adsorpsi Co(II) oleh montmorilonit (Bhattacharyya and Gupta, 2007) dan smectit (Guerra and Airoldi, 2008), tetapi order-pertama pseudo pada kaolinit (Yavuz et al., 2003) dan difusi filem pada bentonit (Shahwan et al., 2006).

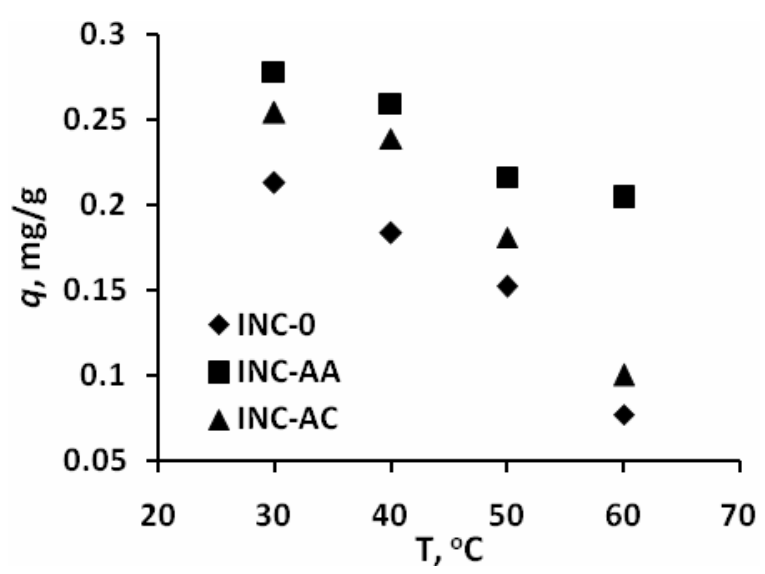

Gambar 6. Pola adsorpsi kation Co(II) oleh lempung Cengar pada berbagai temperatur $\left(\mathrm{C}_{0}=3 \mathrm{mgl}^{-1}, \mathrm{t}=120\right.$ menit, $\mathrm{r}=120 \mathrm{rpm}, \mathrm{pH}=3,8$ )

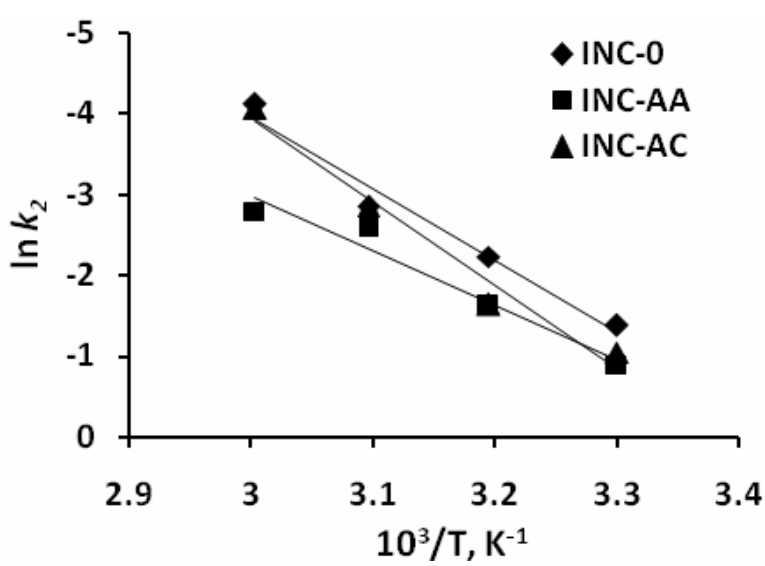

Gambar 7. Grafik hubungan temperatur dengan tetapan laju order-kedua pseudo adsorpsi Co(II) oleh lempung Cengar

Di samping itu dari nilai $\beta$ (model Elovich) yang cukup besar menggambarkan kecenderungan energi aktivasi proses adsorpsi, maka energi aktivasi $\mathrm{E}_{\mathrm{a}}$ dari sistem adsorpsi dapat dihitung menggunakan persamaan Arrhenius di bawah ini:

$$
\ln \mathrm{k}_{2}=\ln \mathrm{A}-\frac{\mathrm{E}_{\mathrm{a}}}{\mathrm{RT}}
$$

dengan $\mathrm{k}_{2}$ tetapan laju order-kedua pseudo, A faktor preeksponensial, $\mathrm{R}$ tetapan gas universal $\left(8,31451 \mathrm{JK}^{-1} \mathrm{~mol}^{-1}\right)$ dan T temperatur absolut (K). Plot ln $\mathrm{k}_{2}$ versus $1 / \mathrm{T}$ disajikan pada Gambar 7 dengan $\mathrm{E}_{\mathrm{a}}$ 
masing-masing: INC-O, INC-AA dan INC-AC adalah $-73,9 ;-55,9$ dan $-85,7 \mathrm{kJmol}^{-1}$. Energi aktivasi yang bernilai negatif dimaknai sebagai energi termal yang tersedia melebihi energi rintangan yang diperlukan (Borah and Mahiuddin, 2008), sehingga terjadi pelepasan energi. Menurut Weng (2008), para pakar telah mendapatkan rentang nilai energi aktivasi 1,2 9,5 $\mathrm{kJmol}^{-1}$ mengikuti mekanisme fisisorpsi, sedang 9,5 - 95,5 $\mathrm{kJmol}^{-1}$ adalah kemisorpsi, karena itu sistem adsorpsi Co(II) - lempung Cengar ini mengikuti mekanisme kemisorpsi.

Secara umum tampak bahwa lempung Cengar yang diimpregnasi (INC-AA dan INC-AC) menunjukkan prestasi dan laju adsorpsi yang lebih tinggi dari pada kontrol (INC-O) dengan waktu dan temperatur adsorpsi yang sama. Impregnasi menyebabkan permukaan lempung Cengar relatif homogen dibandingkan keadaan awalnya, sehingga menambah jumlah situs adsorpsi pada permukaan lempung Cengar dengan jumlah Co(II) yang teradsorpsi pada kesetimbangan masing-masing 70,9; 92,6 dan 88\% untuk INC-O, INC-AA dan INC-AC. Meskipun laju adsorpsi awal (h dan $\alpha$, Tabel 1) cukup tinggi dibandingkan tetapan laju $\mathrm{k}_{2}$, namun laju awal pada lapisan batas ini tidak berpengaruh pada sistem adsorpsi kation Co(II)-lempung Cengar sesuai dengan analisis model intra-partikel.

\section{KESIMPULAN}

Lempung Cengar dapat mengadsorpsi kation Co(II) dalam larutan air dan kapasitas adsorpsinya meningkat setelah lempung diimpregnasi dengan ammonium asetat dan ammonium klorida. Kapasitas adsorpsi juga meningkat dengan waktu kontak dan menurun dengan temperatur. Interaksi kation Co(II) lempung Cengar mengikuti mekanisme kinetika orderkedua pseudo. Pemenuhan terhadap model ini menandakan adsorpsi $\mathrm{Co}$ (II) terjadi secara kemisorpsi di permukaan lempung Cengar, ini sesuai dengan nilai energi aktivasi. Pengujian dengan model Elovich didapatkan permukaan lempung Cengar sangat heterogen.

\section{DAFTAR PUSTAKA}

Abu-Eishah, S.I., (2008), Removal of $\mathrm{Zn}, \mathrm{Cd}$, and Pb Ions from Water by Sarooj clay, Applied Clay Science, 42, pp. 201-205.

Al-Degs, Y.S., El-Barghouthia, M.I., Issaa, A.A., Khraishehb, M.A., and Walker, G.M., (2006), Sorption of $\mathrm{Zn}(\mathrm{II}), \mathrm{Pb}$ (II), and $\mathrm{Co}(\mathrm{II})$ using Natural Sorbents: Equilibrium and Kinetic Studies, Water Research, 40, pp. 2645-2658.

Anirudhan, T.S. and Radhakrishnan, P.G., (2008), Thermodynamics and Kinetics of Adsorption of $\mathrm{Cu}$ (II) from Aqueous Solutions onto a New Cation Exchanger derived from Tamarind Fruit shell, J. Chem. Thermodynamics, 40, pp.702-709.
Argun, M.E., Dursun, S., Ozdemir, C., and Karatas, M., (2007), Heavy Metal Adsorption by Modified Oak sawdust: Thermodynamics and Kinetics, Journal of Hazardous Materials, 141, pp. 77-85.

Bellir, K., Bencheikh-Lehocine, M., Meniai, A.-H., and Gherbi, N., (2005), Study of the Retention of Heavy Metals by Natural Material used as a Liners in Landfills, Desalination, 185, pp. 111-119.

Bhattacharyya, K.G. and Gupta, S.S., (2006), Kaolinite, Montmorillonite, and Their Modified Derivatives as Adsorbents for Removal of $\mathrm{Cu}$ (II) from a Aqueous Solution, Separation and Purification Technology, 50, pp. 388-397.

Bhattacharyya, K.G. and Gupta, S.S., (2007), Adsorptive Accumulation of $\mathrm{Cd}(\mathrm{II}), \mathrm{Co}(\mathrm{II}), \mathrm{Cu}(\mathrm{II})$, $\mathrm{Pb}(\mathrm{II})$ and $\mathrm{Ni}(\mathrm{II})$ from Water on Montmorillonite: Influence of Acid Activation, Journal of Colloid and Interface Science, 310, pp. 411-424.

Bhattacharyya, K.G. and Gupta, S.S., (2008a), Influence of Acid Activation on Adsorption of Ni(II) and $\mathrm{Cu}(\mathrm{II})$ on Kaolinite and Montmorillonite: Kinetic and Thermodynamic Study, Chemical Engineering Journal, 136, pp. 1-13.

Bhattacharyya, K.G. and Gupta, S.S., (2008b), Kaolinite and Montmorillonite as Adsorbents for $\mathrm{Fe}(\mathrm{III}), \mathrm{Co}(\mathrm{II})$ and $\mathrm{Ni}$ (II) in a Aqueous Medium, Applied Clay Science, 41, pp. 1-9.

Borah, J.M. and Mahiuddin, S., (2008), Adsorption and Surface Complexation of Trimesic Acid at the $\alpha$ alumina-electrolyte Interface, Journal of Colloid and Interface Science, 322, pp. 6-12.

Crini, G., Peindy, H.N., Gimbert, F., and Robert, C., (2007), Removal of C.I Basic Green 4 (Malachite Green) from Aqueous Solutions by Adsorption using Cyclodextrin-based Adsorbent: Kinetic and Equilibrium Studies, Separation and Purification Technology, 53, pp.97-110.

da Fonseca, M.G., de Oliveira, M.M., Arakaki, L.N.H., Espiola, J.G.P., and Airoldi, C., (2005), Natural Vermiculite as an Exchanger Support for Heavy Cations in Aqueous Solution, Journal of Colloid And Interface Science, 285, pp.50-55.

Echeverria, J.C., Churio, E., and Garrido, J., (2002), Retention Mechanisms of Cd on Illite, Clays and Clay Minerals, 50, pp. 614-623.

Erdem, E., Karapinar, N., and Donat, R., (2004), The Removal of Heavy Metal Cations by Natural Zeolites, Journal of Colloid And Interface Science, 280, pp. 309-314.

Eren, E. and Afsin, B., (2008), An Investigation of $\mathrm{Cu}$ (II) Adsorption by Raw and Acid-activated 
Bentonite: A Combined Potentiometric, Thermodynamic, XRD, IR, DTA Study, Journal of Hazardous Materials, 151, pp. 682-691.

Gozen, B., Zehra, A.A., and Zafor, O.M., (1998), Removal of $\mathrm{Pb}(\mathrm{II}), \mathrm{Cd}(\mathrm{II}), \mathrm{Cu}(\mathrm{II})$ and $\mathrm{Zn}$ (II) from Aqueous Solutions by Adsorption on Bentonite, Journal of Colloid and Interface Science, 182, pp. 338-343.

Guerra, D.L. and Airoldi, C., (2008), Anchored Thiol Smectite Clay- Kinetic and Thermodynamic Studies of Divalent Copper and Cobalt Adsorption, Journal of Solid State Chemistry, 181, pp. 2507-2515.

Gupta, S. and Babu, B.V., (2009), Removal of Toxic Metal Cr(VI) from Aqueous Solutions using Sawdust as Adsorbent: Equilibrium, Kinetics and Regeneration Studies, Chemical Engineering Journal, 150, pp. 352365 .

Gupta, S.S. and Bhattacharyya, K.G., (2005), Interaction of Metal Ions with Clays: I. A Case Study with Pb(II), Applied Clay Science, 30, pp.199-208.

Gupta, S.S. and Bhattacharyya, K.G., (2008), Immobilization of $\mathrm{Pb}(\mathrm{II}), \mathrm{Cd}(\mathrm{II})$ and $\mathrm{Ni}(\mathrm{II})$ Ions on Kaolinite and Montmorillonite Surfaces from Aqueous Medium, Journal of Environmental Management, 87, pp. $46-58$.

Ho, Y-S., (2006), Review of Second-order Models for Adsorption Systems, Journal of Hazardous Materials $B$, 136, pp. 681-689.

Mane, V.S., Mall, I.D., and Srivasta, V.C., (2007), Kinetic and Equilibrium Isotherm Studies for the Adsorptive Removal of Brilliant Green Dye from Aqueous Solution by Rice husk ash, Journal of Environmental Management, 84, pp. 390-400.

Manohar, D.M., Noeline, B.F., and Anirudhan,T.S., (2006), Adsorption Performance of Al-pillared Bentonite Clay for the Removal of Cobalt(II) from Aqueous Phase, Applied Clay Science, 31, pp.194206.

Miranda-Trevino, J.C. and Coles, C.A., (2003), Kaolinite Properties, Structure and Influence of Metal Retention on pH, Applied Clay Science, 23, pp. 133139.
Nadeem, R., Nasir, M.H., and Hanif, M.S., (2009), Pb (II) Sorption by Acidically Modified Cicer arientinum biomass, Chemical Engineering Journal, 150, pp. 4048 .

Naiya, T.K., Chowdhury, P., Bhattacharya, A.K., and Das, S.K., (2009), Sawdust and Neem bark as Lowcost Natural Biosorbent for Adsorptive Removal of $\mathrm{Zn}(\mathrm{II})$ and $\mathrm{Cd}(\mathrm{II})$ ions from Aqueous Solutions, Chemical Engineering Journal, 148, pp. 68-79.

Noroozifar, M., Khorasani-Motlagh, M., and Fard, P.A., (2009), Cyanide Uptake from Wastewater by Modified Natrolite Zeolite-Iron Oxyhydroxide system: Application of Isotherm and Kinetic models, Journal of Hazardous Materials, 166, pp. 1060-1066.

Peric, J., Trgo, M., and Medvidovic, N.V., (2004), Removal of Zinc, Copper and Lead by Natural Zeolite - a Comparison of Adsorption Isotherms, Water Reseach, 38, pp.1893-1899.

Prayitno, B.A., (2008), Dampak Penggunaan Air Tercemar untuk Irigasi Pertanian dan Rekomendasi Penanganannya, dalam website http://baskorol.blogspot.com/2008/03/dampakpenggunaan-air-tercemar-untuk.html, (22 Maret 2008).

Shahwan, T., Erten, H.N., and Unugur, S., (2006), Priority Communication: A Characterization Study of some Aspect of the Adsorption of Aqueous $\mathrm{Co}^{2+}$ Ions on Natural Bentonite Clay, Journal of Colloid And Interface Science, 300, pp. 447-452.

Weng, C-H., Sharma, Y.C., and Chua, S-H., Adsorption of $\mathrm{Cr}(\mathrm{VI})$ from Aqueous Solutions by Spent Activated Clay, Journal of Hazardous Materials, 155, pp. 65-75.

Yavuz, O., Altunkaynak, Y., and Guzel, F., (2003), Removal of Copper, Nickel, Cobalt and Manganese from Aqueous Solution by Kaolinite, Water Research, 37, pp. 948-952.

Yu, B., Zhang, Y., Shukla, A., Shukla, S.S. and Dorris, K.L., (2000), The Removal of Heavy Metal from Aqueous Solutions by Sawdust AdsorptionRemoval of Copper, Journal of Hazardous Materials B, 80, pp. 33-42. 